\title{
HUBUNGAN USIA DENGAN KEJADIAN ANEMIA PADA IBU HAMIL DI KOTA METRO
}

\section{RELATIONSHIP OF AGE WITH ANEMIA IN PREGNANT MOTHERS IN METRO CITY}

\author{
Senja Atika Sari HS, Nuri Luthfiatil Fitri, Nia Risa Dewi \\ Akper Dharma Wacana Metro ${ }^{1,2,3}$ \\ Email : senjahs27@gmail.com
}

\begin{abstract}
ABSTRAK
Kehamilan yang mengalamai anemia umumnya terkait dengan adanya perubahan fisiologis yang terjadi dalam kehamilan. Terjadinya ekspansi volume plasma berhubungan erat dengan terjadinya penurunan relatif konsentrasi hemoglobin disamping pertumbuhan janin yang membutuhkan besi dan folat semakin menempatkan ibu hamil rentan atau berisiko tinggi menderita defiensi. Tujuannya untuk mengetahui hubungan usia dengan anemia pada ibu hamil di Kota Metro. Penelitian ini memakai metode desain studi analitik dengan pendekatan cross sectional. Besar sampel diambil berdasarkan odds ratio (OR) menggunakan rumus Lemeshow. Besar sampel yang digunakan adalah 138 orang. Analisis data dialkukan uji chi-square. Hasil terdapat hubungan antara usia dengan kejadian anemia pada ibu hamil dimana ibu hamil diusia dibawah 20 tahun dan diatas usia 35 tahun berisiko 3,921 kali lebih besar kemungkinan anemia dalam kehamilannya diperbandingkan dengan ibu hamil pada usia antara 20 sampai dengan 35 tahun. Ibu yang mengalami kehamilan pada usia dibawah 20 tahun masukan zat besi akan terbagi antara janin yang ada dirahimnya dengan pertembuhan biologis dirinya sendiri. Ibu yang hamil > 35 tahun, sudah memasuki masa awal fase degenerative, sehingga fungsi tubuh tidak optimal. Kehamilan diusia dibawah 20 tahun dan diatas 35 tahun adalah kehamilan yang memiliki resiko dan bisa menimbulkan anemia. Kesimpulan usia ibu saat hamil terbukti berhubungan dengan anemia, oleh karena itu sebaiknya ibu jika ingin hamil pada usia diatas 20 tahun dan atau di bawah 35 tahun.
\end{abstract}

Kata Kunci : Anemia, kehamilan

\begin{abstract}
ABSTRAK
Pregnancy with anemia is generally associated with physiological changes that occur during pregnancy. The occurrence of plasma volume expansion is closely related to the occurrence of a relative decrease in hemoglobin concentration in addition to the growth of the fetus which requires iron and folate, which puts pregnant women at high risk of suffering from deficiency. The aim is to determine the relationship between age and anemia in pregnant women in Metro City. This study uses an analytical study design method with a cross sectional approach. The sample size was taken based on the odds ratio (OR) using the Lemeshow formula. The sample size used is 138 people. Data analysis was performed by chi-square test. The results show that there is a relationship between age and the incidence of anemia in pregnant women where pregnant women under the age of 20 years and above the age of 35 years have a 3.921 times greater risk of anemia in pregnancy compared to pregnant women between the ages of 20 to 35 years. Mothers who experience pregnancy at the age of under 20 years of iron intake will be divided between the fetus in the womb and their own biological growth. Mothers who are pregnant $>35$ years, have entered the early degenerative phase, so that body functions are not optimal. Pregnancy under the age of 20 years and above 35 years is a pregnancy that has a risk and can cause anemia. The conclusion is that maternal age during pregnancy has been shown to be associated with anemia, therefore it is better if the mother wants to get pregnant at the age of over 20 years and or under 35 years.
\end{abstract}

Keywords: Anemia, pregnancy 


\section{PENDAHULUAN}

Anemia ialah kejadian dimana sel darah merah dan hemoglobin di darah kurang cukup dalam mencukupi yang dibutuhkan tubuh. Anemia yang timbul dalam kehamilan umumnya dipengaruhi oleh fisiologis selama hamil, usia kehamilan dan keadaan ibu hamil. Terjadinya ekspansi volume plasma (paling tinggi pada umur kehamilan 24 minggu serta terus meningkat hingga 37 minggu) berhubungan erat dengan terjadinya penurunan relatif konsentrasi hemoglobin disamping pertumbuhan janin yang membutuhkan besi dan folat semakin menempatkan ibu hamil rentan atau berisiko tinggi menderita defiensi. Pada perempuan yang sedang hamil walaupun telah diberikan suplemen besi tambahan dan selama kehamilan peneyerapan zat besi meningkat umumnya perempuan yang hamil dengan cadangan besi yang rendah akan tetap gagal dalam memenhui kebutuhan zat besi dimana diperlukan oleh tubuh hingga akhirnya timbul anemia ${ }^{1}$.

Berdasarkan Rikesdas 2013 proporsi anemia ibu hamil yaitu $37,1 \%$. Jumlah tertinggi terjadi di wilayah pedesaan yaitu sebesar $37,8 \%$ dan terendah terjadi di perkotaan sebesar $36,4 \%{ }^{2}$. Sementara pada Riskesdas 2018 angka kejadian anemia ibu hamil adalah sebesar 48,9\%. Jumlah tertinggi kasus anemia ibu hamil juga masih didominasi di wilayah pedesaan yaitu mencapai $49,5 \%$ sementara di perkotaan adalah sebesar $48,3 \%$ 3.

Upaya mencegah anemia dalam meningkatkan kesehatan ibu hamil ialah dengan memberikan tablet $\mathrm{Fe}$ sejumlah 90 tablet. Variasi jumlah kepatuhan tablet $\mathrm{Fe}$ ibu selama kehamilan di Indonesia sebesar 87,6 persen ${ }^{3}$. Cakupan tablet Fe 3 pada ibu hamil secara nasional tahun 2018adalah sebesar81,16\%, dimana jumlah ini belum memenuhi harapan Renstra tahun 2018 sebesar 95\%, cakupan tertinggi berada di Provinsi Bengkulu $(99,49 \%)$ dan terendah di Banten (32,11\%), sementara di Provinsi Lampung adalah sebesar $90,10 \%{ }^{4}$. Tablet $\mathrm{Fe}$
1 di Kota Metro yang diberikan pada ibu hamil tahun 2018 mencapai 100\% dan Fe 3 sebesar 99\%, dan dari 12 Puskesmas yang ada seluruhnya telah mencapai target $(90 \%)^{5}$. Pada kejadian anemia ibu hamil salah satu factor yang mempengaruhi adalah usia ibu saat hamil. Wanita hamil di usia dibawah 20 tahun dimana pada usia tersebut diketahui bahwa organ dalam tubuhnya masih dalam proses pematangan dan perkembangan salah satunya sistem reproduksi. Untuk memenuhi perkembangan reproduksi tubuhnya masih butuh banyak suplai berbagai zat gizi, sehingga jika terjadi kehamilan di usia ini tentunya kebutuhan zat gizi akan meningkat dibanding wanita yang hamil diatas 20 tahun. Zat gizi yang diperlukan tubuh jika tidak tepenuhi tentunya akan mengakibatkan anemia. Pada wanita hamil usia diatas 35 tahun juga beresiko anemia dikarenakan kemampuan daya tahan tubuh sudah mulai menurun dan beresiko mengalamai berbagai masalah kehamilan salah satunya anemia ${ }^{6}$.

Berdasarkan latar belakang diatas maka hasil yang ingin diketahui adakah hubungan antara usia ibu terhadap anemia pada ibu hamil di Kota Metro.

\section{METODE}

Studi analitik menggunakan rancangan cross sectional. Populasi adalah ibu hamil di Kota Metro tahun 2019 dan sampel penelitian yang digunakan sebanyak 138 orang. Besar sampel diambil berdasarkan odds ratio (OR) menggunakan rumus Lemeshow.

Tehniknya dengan data sekunder diperoleh dari Puskesmas se-Kota Metro, Lampung. Analisis dilakukan menggunakan uji chisquare.

\section{HASIL}

Tabel 1

Distribusi Frekuensi Usia Ibu

\begin{tabular}{lcc}
\hline No Variabel & $\boldsymbol{f}$ & $\boldsymbol{\%}$ \\
\hline 1 Usia Ibu & & \\
Risiko Tinggi $(<20 \&>35)$ & 33 & 23,9 \\
Risiko Rendah $(20-35)$ & 105 & 76,1 \\
\hline \multicolumn{2}{c}{ Jumlah 138} & 100,0 \\
\hline
\end{tabular}


Tabel tersebut dijelaskan dari 138 ibu hamil, mayoritas diusia 20-35 tahun yaitu 105 orang $(76,1 \%)$ dan 33 orang $(23,9 \%)$ berusia $<20 \&$ $>35$ tahun.

\section{Tabel 2}

Hubungan Usia dengan Anemia Pada Ibu Hamil

\begin{tabular}{|c|c|c|c|}
\hline Variabel & $\Sigma$ & $\boldsymbol{P}$ & $\begin{array}{c}\text { OR } \\
(95 \% C I)\end{array}$ \\
\hline & $n \%$ & & \\
\hline $\begin{array}{l}\text { Resiko } \\
\text { tinggi } \\
\text { Resiko } \\
\text { rendah } \\
\text { Jumlah }\end{array}$ & 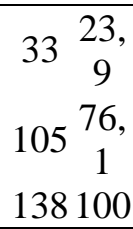 & 0,001 & $3,921(1,731-8,878)$ \\
\hline
\end{tabular}

Hasil analisis bivariat pada variabel usia, dari 33 ibu ada dirisiko tinggi dibawah 20 dan diatas 35 tahun. Ibu yang ada diresiko rendah antara usia 20 sampai 35 tahun berjumlah 105 orang. Hasil analisis uji beda proporsi diperolehnilai $p=0,001(p<0,05)$; OR: 3,921 (CI;95\% 1,731-8,878), artinya secara statistik diyakini terdapat hubungan antara usia dengan kejadian anemia pada ibu hamil dimana ibu yang hamil diusia dibawah 20 dan lebih dari 35 tahun memiliki resiko 3,921 kemungkinan menderita anemia dalam kehamilannya dari pada ibu yang hamil di usia antara 20 sampai 35 tahun.

\section{PEMBAHASAN}

Kehamilan merupakan sebuah proses yang fisiologi sehingga seorang ibu perlu melakukan perencanaan dalam kehamilannya dengan mempertimbangkan berbagai faktor yang dapat mempengaruhi kondisi kesehatan ibu maupun janin diantaranya adalah faktor usia. Berdasarkan hasil penelitian,dari 33 ibu berada diusia dibawah 20 atau >35 tahun ditemukan sejumlah 19 ibu $(41,3 \%)$ menderita anemia serta $14 \mathrm{ibu}(15,2 \%)$ tidak mengalami anemia. Selanjutnya 105 orang yang berada pada usia antara 20 sampai 35 tahun. 78 orang $(84,8 \%)$ ibu hamil tidak menderita anemia sedangkan yang melamai anemia hanya $(58,7 \%) 27$ orang. Hasil analisis uji beda proporsi membuktikan bahwa faktor usia terbukti berhubungan dengan kejadian anemia ( $p$ value $=0,001)$, dimanapada confidence interval $95 \%$ diyakini ibu hamil yang berusia dibawah 20 dan diatas 35 tahun berisiko menderita anemia 3,921 kali kemungkinan dari pada ibu hamil diusia antara 20-35tahun. Keterkaitan antara faktor usia dan kejadian anemia dipenelitian yang dilakukan sesuai antara penelitian sebelumnya bahwa umur ibu saat hamil pada usia dibawah 20 tahun dan usia diatas 35 tahun mempunyai kemungkinan 2 kali menderita anemia dari pada ibu hamil yangberusia antara rentang 20 sampai 35 tahun saat hamil ${ }^{8}$. Hasil dari penelitian sesuai antara penelitian Tanziha, Damik \& Rosmiati yang menganalisis faktor resiko anemia ibu hamil di Indonesia dengan mengambil data hasil Riskesdas 2013, bahwa anemia pada kehamilan lebih tinggi terjadi pada wanita yang hamil dibawah 20 tahun atau diatas 35 tahun dibanding wanita hamil rentang usia 20 sampai 35 tahun baik ibu di daerah perkotaan maupun daerah perdesaan ${ }^{9}$. Masa kehamilan sangat rentan terhadap terjadinya kekurang zat besi karena selama kehamilan, zat besi akan lebih banyak dibutuhkan terutama untuk memasok janin dan plasenta yang sedang tumbuh dan untuk meningkatkan massa sel darah merah ibu ${ }^{10}$. Pada kondisi yang membutuhkan banyak zat besi, maka kehamilan yang terjadi pada wanita berusia sangat muda atau sangat tua akan rentan terhadap terjadinya anemia. Usia tergolong sangat muda ialah usia dibawah 20 tahun dan yang tergolong terlalu tua adalah >35 tahun sementara usia yang dianggap aman bagi kehamilan ialah usia 20 sampai 35 tahun dikarenakan sudah siap hamil secara fisik dan kejiwaan ${ }^{11}$. Ibu yang hamil pada usia $<20$ tahun konsumsi besi terbagi dengan janin didalam rahim dan pertembuhan biologis dirinya sendiri yang tentunya masih memerlukan banyak asupan zat besi. Ibu yang hamil >35 tahun, sudah memasuki masa awal fase degenerative, sehingga fungsi tubuh tidak optimal dan 
mengalami berbagai masalah kesehatan. Kehamilan diusia dibawah 20 serta diatas 35 tahun adalah kehamilan yang memiliki resiko anemia ${ }^{9}$.

\section{KESIMPULAN}

Hasil penelitian diatas kesimpulannya bahwa dari 138 ibu hamil yang menjadi responden lebih banyak berusia pada rentang usia 20 sampai 35 tahun $(76,1 \%)$ atau berada pada usia reproduksi sehat. Hasil analisis uji beda proporsi diperoleh nilai $p=0,001(p<0,05)$; OR: 3,921 (CI;95\% 1,731-8,878), artinya secara statistik diyakini terdapat hubungan usia dengan terjadinya anemia pada ibu hamil dimana ibu yang hamil dibawah 20 tahun dan wanita yang hamil diatas usia 35 tahun beresiko 3,921 kali lebih besar kemungkinan menderita anemia dalam kehamilannya dari pada Wanita hamil direntang usia antara 20 sampai 35 tahun.

\section{DAFTAR PUSTAKA}

1. Laksmi, P. W., Mansjoer, A., Alwi, I., Setiati, S. \& Ranitya, R. PenyakitPenyakit Pada Kehamilan Peran Seorang Internis. (Interna Publishing FKUI, 2012).

2. Kemenkes RI. Riset Kesehatan Dasar 2013. (Badan Penelitian dan Pengembangan Kesehatan RI, 2013).

3. Kemenkes RI. Laporan Nasional Riset Kesehatan Dasar 2018. (2019)

4. Kemenkes RI. Profil Kesehatan Indonesia 2018. (Direktorat Jenderal Kesehatan Masyarakat - Ditjen P2P, 2019).

5. Dinkes Kota Metro. Profil Kesehatan Kota Metro 2018. (2019).

6. Rahmaniah, Linda, P.S. Hubungan umur ibu dan paritas dengan kejadian anemia pada ibu hamil. Journal of Health, Education and Literacy (2019)

7. Notoatmodjo, S. Metodologi Penelitian Kesehatan (Edisi Revisi). (PT. Rineka Cipta, 2012).

8. Ristica, O. D. Faktor Risiko Kejadian
Anemia pada Ibu Hamil. J. Kesehat. Komunitas 2, 78-82 (2013).

9. Tanziha, I., Utama, L. J. \& Rosmiati, R. Faktor Risiko Anemia Ibu Hamil Di Indonesia. 11, 143-152 (2016)

10. Suitor, C. W. Perspectives on nutrition during pregnancy: Part I, weight gain; part II, nutrient supplements. Journal of the American Dietetic Association 91, (1991)

11. Kemenkes RI. Buku Pedoman Pengenalan Tanda Bahaya Kehamilan, Persalinan dan Nifas. (2017). 